\title{
使用済み太陽光発電パネルのガラス再資源化による環境負荷削減効果 ENVIRONMENTAL LOAD REDUCTION EFFECT BY RECYCLING USED PHOTOVOLTAIC GENERATION PANEL GLASS
}

\author{
湯淺和 博*, 鶴崎敬大**, 山崎 成 ${ }^{* * *}$ \\ Kazuhiro YUASA, Takahiro TSURUSAKI and Sei YAMASAKI
}

\begin{abstract}
Considering future's enormous volume disposal of photovoltaic generation panels, it's an urgent problem to find recycling method of that. This research estimates $\mathrm{CO}_{2}$ reduction effect by the recycling of photovoltaic generation panels through the inventory analysis. In order to considerate more efficient recycling method, it was analyzed targeted for several kinds of recycled products such as ceramic tile, block, and soundproof panel. Results showed that $\mathrm{CO}_{2}$ reduction effect was confirmed about all targeted recycling products. In particular, the environmental load reduction effect by the recycling to the ceramic tile was remarkable.
\end{abstract}

Keywords : Photovoltaic Panel, Recycling, Glass, Inventory Analysis, Reducing $\mathrm{CO}_{2}$ Emissions 太陽光発電パネル，再資源化，ガラス，インベントリ分析， $\mathrm{CO}_{2}$ 削減

\section{1. はじめに}

近年, 環境への配慮や固定価格買取制度などを背景に太陽光発電 の導入が家庭用, 産業用ともに増大傾向にあるが, 将来的な太陽光 発電パネル（以下 PV パネル）の大量廃棄が懸念されている。平成 28 年 3 月, 環境省により太陽光発電設備のリサイクルに関するガイ ドライン ${ }^{1)}$ が発表され, 使用済み PV パネルについても今後, 再資 源化に向けた動きが高まっていくと考えられる。PV パネルの廃棄量 はその寿命を 25 年とした場合, 2040 年には 80 万 $\mathrm{t}$ に達するという 試算がなされているが ${ }^{2)}$, この廃棄量は現在の日本全体の最終処分 量の $6 \%$ に相当し, 今後の最終処分場への負荷を考慮すると, その 影響は甚大である。また, PV パネルのリサイクルと同時にリユース に関しても検討がなされているが，流通量は現在極めて少ない2）。

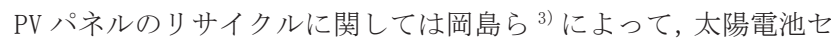
ル部分の再資源化に関する検討がなされており，従来の製造法と比 較して投入エネルギー, $\mathrm{CO}_{2}$ 抑制効果が得られることを明らかにして いる。しかし, PV パネルの主要構成材料は重量比で $50 \%$ 以上を占め る表面保護を目的としたカバーガラスであり, 廃棄物の減容化とい う視点からはこれらの処理についても検討する必要がある。

PV パネルに用いられるガラスは製品の性質上, 総じて高い透過性 と耐久性が要求され, 一般的な製品と比較して品質的に優れている。 これらをリサイクル原料として利用することは加工二次製品の品質 を担保する上で有効である。ガラスのリサイクルに関して, 醍醐ら
4) 5) は, びん, ガラス繊維, 建築用および廃自動車の板ガラスの再 資源化に関する評価を行っており，その環境性について言及してい る。清家ら ${ }^{6)}$ は板ガラス等の建材に対して他産業を含めたマテリア ルフローに基づいた再資源化評価を行っている。茂呂ら ${ }^{7)}$ もンケ 一ト調查に基づく, リサイクル資材製造時の環境負荷原単位の整備 を実施しており, 一部, 廃ガラスを原料とした製品についても製造 時の環境負荷原単位を算定している。

以上のように, 廃ガラスの再資源化を行うことで環境負荷削減効 果が得られることは定性的には言及され, PV パネルを対象とした再 資源化の実証試験が進みつつあるが, 将来の普及促進に向けて定量 的な効果を明らかにすることが求められている。本研究では国内の ガラスを対象とした再資源化製品を取り扱う業者を対象にヒアリン グ調査を実施し, 実際の処理工程を考慮した PV パネルのガラスを再 資源化した際の環境負荷削減効果について, インベントリ分析を用 いて評価することを目的とした。

なお, 本論文は 2016 年度日本建築学会大会学術講演 ${ }^{15)}$ 16) におい て発表した内容に新たな分析結果を加え，作成したものである。

2. インベントリ分析に関する前提条件

2.1 インベントリデータの収集

分析に必要となるインベントリデータの収集を目的に国内の PV パネル処理業者，ガラス再資源化製品の製造メーカーなどを対象に
* 東京工業大学環境 · 社会理工学院 准教授 $\cdot$ 工博

** 東京工業大学大学院理工学研究科 博士課程 (株)住環境計画研究所)

*** 東京工業大学大学院理工学研究科 修士課程 （現在（株竹中工務店）
Assoc. Prof., School of Environment and Society, Tokyo Institute of Technology, Dr.Eng. Grad. Student, Graduate School of Science and Engineering, Tokyo Institute of Technology (Jyukankyo Research Institute Inc.)

Grad. Student, Graduate School of Science and Engineering, Tokyo Institute of Technology (Currentry, Takenaka Corporation) 
ヒアリング調査を実施した。調査概要を表 1 に示す。調査項目はP P パネルの中間処理や再資源化製品製造の処理工程, 加工機器仕様, 燃料消費量などである。また, 使用済み PV パネルの中間処理業者か らは PV パネル (本研究では単結晶系, 多結晶系, アルミナ薄膜系, ソーダ石灰薄膜系，化合物系の 5 種類）の材料構成比之有価金属含 有量についても回答を得た。なお，本研究で評価対象とするガラス 再資源化製品はガラス使用率の違いを考慮して, タイル, ブロック, 防音パネルの 3 種類の建材注 1) とした。

\section{2 製品製造工程と評価方法}

図 1 にヒアリング調査を基に設定したインベントリ分析に必要と なる製品製造工程を示す。工程 C は今回の主な評価範囲となる PV パネルをタイルへと再資源化する際の加工工程であり, 集積した PV パネルからアルミフレームを取り除き，カバーガラスを破砕するこ とでガラスカレットを回収, タイルの原料として利用する工程であ る。一方, 工程 A は現状の最も単純なリサイクル方法である, PV パ ネルを破砕した後に製錬処理により溶融スラグ化，路盤材として活 用する工程である。また，本検討では比較対象間の最終製品量を揃 えた評価を行うため，工程 C と同量のタイルを天然原料から製造す る工程 $\mathrm{B}$ ，工程 $\mathrm{A}$ と同量の路盤材を天然原料から製造する工程 D を 設定した。現状工程 $[\mathrm{A}+\mathrm{B}]$ と提案工程 $[\mathrm{C}+\mathrm{D}]$ の $\mathrm{CO}_{2}$ 排出量の比較を行 うことで PV パネルをタイルへと再資源化した際の環境負荷削減効 果を確認する。なお，分析に関してはPV パネル $1 \mathrm{t}$ を処理した場合 を想定した $\mathrm{CO}_{2}$ 排出量（本報では $\left[\mathrm{kgCO} / \mathrm{t}^{\prime}\right]$ と表記）を算定する。

タイルの製造工程である工程 B は原料が天然原料，工程 C は原料 がガラスカレットであるが，ヒアリング調査により，其々の工程に おけるタイル焼成プロセスにおいて燃料消費量に違いが生じるとい う回答を得た。表 2 にタイル焼成時の燃料消費量を示す。タイルの 原料にガラスカレットを用いることで天然原料から作られる一般的 な磁器質タイルを製造するときに比べ，焼成プロセスでの炉内温度 を $1250^{\circ} \mathrm{C}$ から $1100^{\circ} \mathrm{C}$ まで下げることが可能となったことで然料使 用量を約 $33 \%$ 削減でき， $\mathrm{CO}_{2}$ 削減効果を得られることが示唆された。 ブロックと防音パネルヘリサイクルする場合, 図 1 の工程 B と C を それぞれ図 2,3 に示した工程に置き換え，算定した。なお，これら 2 つの製品の工程 B については，天然原料から製品を作る場合のデ ータをヒアリング調查から得られなかったため, 既に市場で流通し ているガラスカレット（びん製品や建材由来のガラスから発生する もの）を原料とする工程を設定した。

表 1 ヒアリング調査概要

\begin{tabular}{|c|c|c|}
\hline 調查対象 & \multicolumn{2}{|c|}{$\begin{array}{l}\text { 廃棄 P Vパネル加工業者（A社、B社） } \\
\text { ガラスカレット加工業者（C社） } \\
\text { ガラスリサイクル製品製造メーカー（D社、E社) }\end{array}$} \\
\hline 調查期間 & \multicolumn{2}{|l|}{ 2015年10月～11月 } \\
\hline \multirow{5}{*}{ 調査項目 } & 処理工程 & $\begin{array}{l}\text { ·作業工程フローとそれに伴うマテリアルバランス } \\
\text { ·各工程におけ機器の処理量と稼働時間 } \\
\end{array}$ \\
\hline & 加工機器仕様 & $\begin{array}{l}\cdot \text { ·各工程における機器の定格出力 } \\
\text { · 処理能力・機器平均出力率 } \\
\text { · 時間平均燃料消費量 }(\mathrm{LPG} \text {, 都市ガス、A重油等) }\end{array}$ \\
\hline & 生産品仕様 & 寸法、重量、面積等 \\
\hline & 生産量 & 旦間、もしくは月間生産能力 \\
\hline & PVパネル構成比 & $\begin{array}{l}\text { ·材料構成比 } \\
\text { · 有価金属含有量 }\end{array}$ \\
\hline
\end{tabular}

表 2 ガラスカレット利用によるタイル焼成時の燃料消費量

\begin{tabular}{|c|c|c|c|}
\hline & 材料構成 & 焼成温度 ${ }^{\circ} \mathrm{C}$ & $\begin{array}{c}\text { タイル } 1 \mathrm{~m}^{2} \text { } \\
\text { LPG }\end{array}$ \\
\hline 既存磁器質タイ $\mathrm{k} g$
\end{tabular}

\section{2. $3 \mathrm{PV}$ パネルの材料構成比と最終製品量}

表 3 に PV パネルの材料構成比と PV パネル $1 \mathrm{t}$ をリサクルした 際に得られる製品の生産量を示す。ガラスの含有率は単結晶系 (43.9
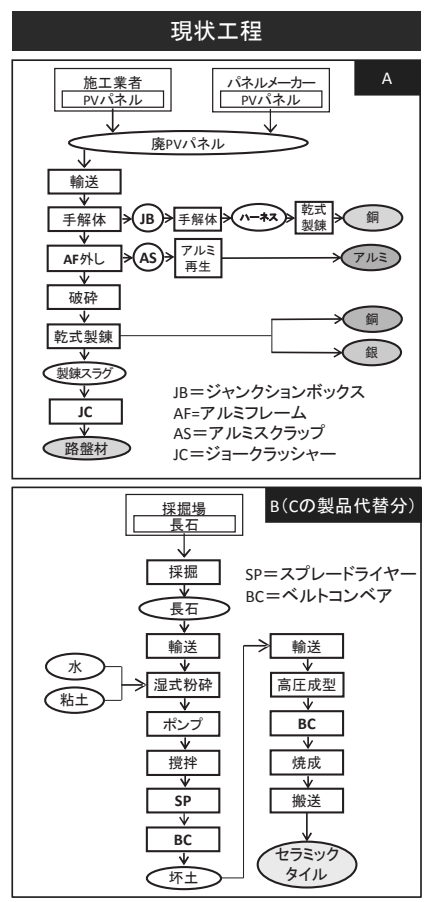

※丸は製品(途中工程も含む) 四角はプロセスを表す。

※B,Clこついて

プロセス: 湿式粉砕に投入される

水、粘土、長石(ガラスカレット)

重量比は其々 $1: 1: 1$ である。

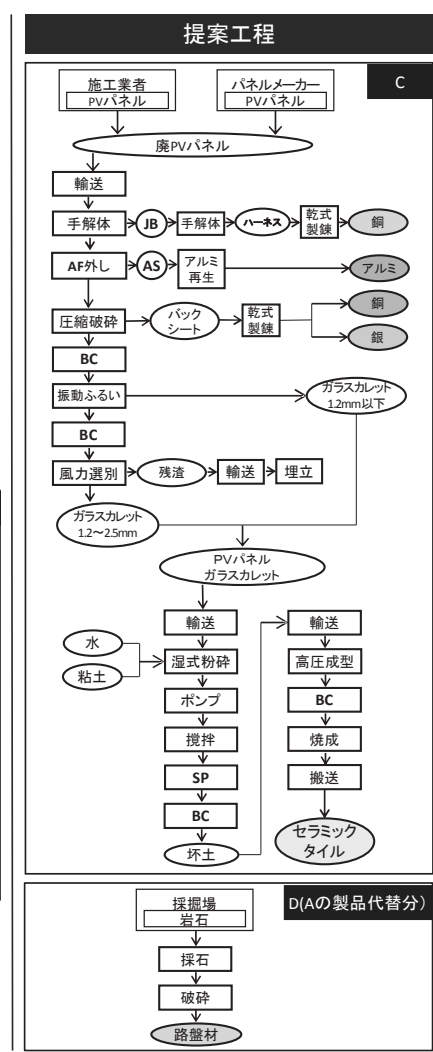

図 1 製品製造工程（タイル製造時）

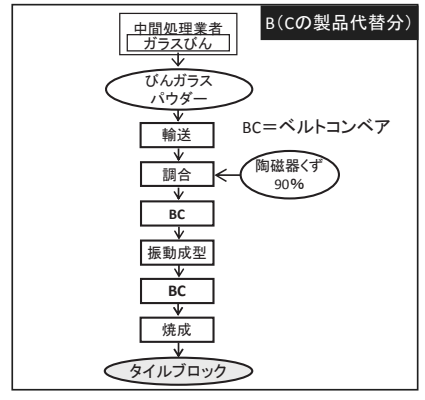

ブロック製造時

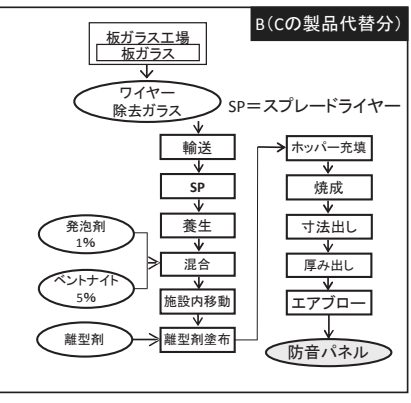

防音パネル製造時
図 2 製品製造工程（工程 B)

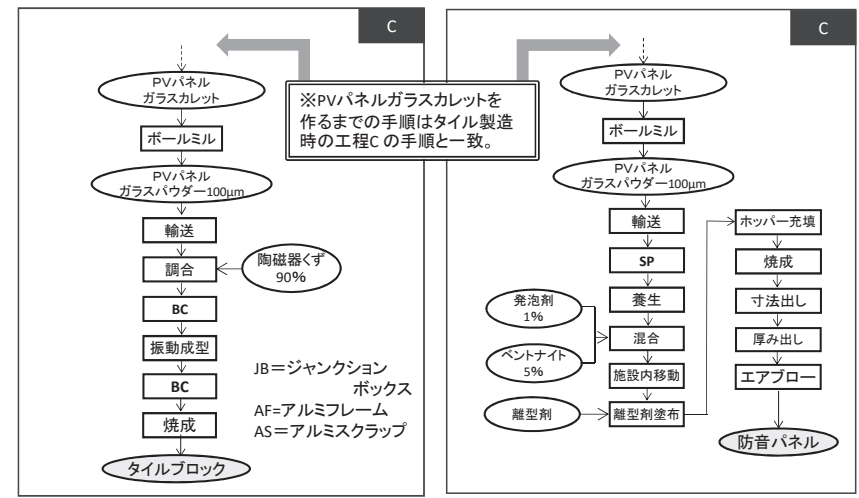

ブロック製造時

防音パネル製造時

図 3 製品製造工程（工程 C) 
$\%), \operatorname{CIGS}$ 系 $(40.0 \%)$ ，多結晶系 $(37.5 \%)$ ，薄膜系（33.0\%）の 順に大きい。アルミフレームの構成比に関しては薄膜系が最も大き く $(33.0 \%)$, 次いで単結晶系 $(20.0 \%)$, 多結晶系 $(16.3 \%)$ であ った。CIGS 系 PV パネルに関しては, 今回の調查対象企業がアルミ フレームを含まないものを取り扱っていたため, 構成比は $0 \%$ であ る。また, 銀と銅は多結晶系 PV パネルにおいて比較的含有量が多く, CIGS 系において最も少ないという結果が得られた。なお, 今回薄膜 系 PV パネルはアルミナ系とソーダ石灰系の 2 種類を取り扱ったが, 材料構成比について個別の結果が得られなかった（両パネルが混成 したものの材料構成比を得た）ため，有価金属含有量においてのみ 差がみられるものとし，ガラス，アルミフレームの量などについて はそれぞれ同值であると仮定して分析を行う。

PV パネルをリサイクルすることで得られる再資源化製品の最終 製品量は, PV パネルのガラス含有量に比例する。例えば, PV パネル $1 \mathrm{t}$ から得られるガラスは単結晶系パネルで $439 \mathrm{~kg}$, 多結晶系パネル で $375 \mathrm{~kg}$ であり,製造できるタイルは其々 $788.4 \mathrm{~kg}, 675.0 \mathrm{~kg}$ となる。 最終製品量はガラス含有率の高い単結晶系 PV パネルで最大となり, タイルは 788. $4 \mathrm{~kg} / \mathrm{t}^{\prime}$ (ガラス使用率 $56 \%$ ), ブロックは $4380.0 \mathrm{~kg} / \mathrm{t}^{\prime}$ (同 $10.0 \%$ )，防音パネルは $461.3 \mathrm{~kg} / \mathrm{t}^{\prime}$ （同 95\%）となった。

\section{4 分析に用いた設定値}

本研究では, 各プロセスにおいて分析に必要となる情報が上記の 調查で捕捉しきれない場合には，表 4 に示した設定值を用いて分析 を行った。輸送プロセスについてはヒアリング対象である実際の工 場などの立地を参考に PV パネル処理業者への集積時には $100 \mathrm{~km}$ ，そ れ以外の輸送プロセスは $50 \mathrm{~km}$ と距離を設定した注2)。

分析に必要となる $\mathrm{CO}_{2}$ 原単位に関しては文献等 ${ }^{8,9)}$ を参考に設定 するが，該当するプロセスの原単位が不明な場合には代替となる原 単位（表 5) を用いて分析を行った。電力消費に関する $\mathrm{CO}_{2}$ 原単位は 電力事業者ごとにその值が公表されているが本研究では特定の電力 事業者の值は用いず，環境省が公表する排出係数に関する代替值 ${ }^{12)}$ $\left(0.579 \mathrm{kgCO}_{2} / \mathrm{kWh}\right)$ を適用した。燃料消費に関しても同様な設定を 行った (LPG: $3.00 \mathrm{kgCO}_{2} / \mathrm{kg}, \mathrm{A}$ 重油: $\left.2.71 \mathrm{kgCO}_{2} / \mathrm{L}\right)$ 。

各プロセスにおける加工機器の仕様を表 6 に示す。機器の効率に 関しては定格出力の值を参考に文献 ${ }^{13)}$ より值を推定し設定を行っ た。また，ここでの平均出力率とは定格出力に対して各機器がどれ ほどの負荷で稼働しているのかを示す值であり，各プロセスにおけ る時間平均の值をヒアリング調査を基に設定した。

\section{3. インベントリ分析}

\section{1 各プロセスの算定結果}

表 7〜10 に工程別 $(\mathrm{A} \sim \mathrm{D})$ の各プロセスにおける $\mathrm{CO}_{2}$ 排出量と，そ の算定式を記載する。ここでは単結晶系 PV パネルをタイルへとリサ イクルする場合の分析結果を示す。電力を使用するプロセスについ ては以下の基本式に基づいて電力消費量を算定した。

電力消費量 $[\mathrm{kWh}]=$ 定格出力 $[\mathrm{kW}] \times$ 平均出力率 $[-] \times$ (処理量 $[\mathrm{kg}] /$ 処理 能力 $[\mathrm{kg} / \mathrm{h}]) /$ 効率 $[-]$

機器の稼働時間は式中の処理量/処理能力に該当するが, 処理が一連 のライン状で進行する部分（例：カテゴリ $\mathrm{C}$ の圧縮破砕〜風力選別） では, 機器の稼働時間は各プロセスで一定であるとし, 工程上で上 流側の機器の稼働時間に依存するものとして算定した。

\section{表 3 PV パネルの材料構成比 [重量\%] と最終製品量 [kg/t']}

\begin{tabular}{|c|c|c|c|c|c|c|c|}
\hline & & & 単結晶系 & 多結晶系 & $\begin{array}{c}\text { 薄膜系 } \\
\text { (アルミ゙) }\end{array}$ & $\begin{array}{c}\text { 薄膜系 } \\
(\text { ○ーダ石死) } \\
\end{array}$ & CIGS系 \\
\hline \multirow{7}{*}{$\begin{array}{c}\text { 材 } \\
\text { 料 } \\
\text { 構 } \\
\text { 成 } \\
\text { 比 } \\
{[\%]}\end{array}$} & & 端子箱 & 1.54 & 1.88 & 3.30 & 3.30 & \\
\hline & \multicolumn{2}{|c|}{ アルミフレーム } & 20.0 & 16.3 & 33.0 & 33.0 & \\
\hline & \multicolumn{2}{|c|}{ バックシート } & 32.8 & 42.2 & 23.3 & 24.0 & 52.9 \\
\hline & \multicolumn{2}{|r|}{ ガラス } & 43.9 & 37.5 & 33.0 & 33.0 & 40.0 \\
\hline & \multicolumn{2}{|r|}{ 銀 } & 0.074 & 0.133 & 0.045 & 0.018 & 0.0036 \\
\hline & \multicolumn{2}{|r|}{ 銅 } & 0.19 & 1.42 & 0.84 & 0.14 & 0.011 \\
\hline & \multicolumn{2}{|r|}{ その他 } & 1.5 & 0.5 & 6.5 & 6.5 & 7.1 \\
\hline \multirow{6}{*}{$\begin{array}{c}\text { 最 } \\
\text { 終 } \\
\text { 製 } \\
\text { 品 } \\
\text { 量 } \\
{\left[\mathrm{kg} / \mathrm{t}^{\prime}\right]}\end{array}$} & \multicolumn{2}{|c|}{ セラミックタイル } & 788.4 & 675.0 & 593.5 & 593.5 & 720.0 \\
\hline & \multicolumn{2}{|r|}{ ブロック } & 4380 & 3750 & 3297 & 3297 & 4000 \\
\hline & \multicolumn{2}{|c|}{ 防音パネル } & 461.3 & 394.9 & 347.2 & 347.2 & 421.3 \\
\hline & \multirow{3}{*}{ 共通 } & アルミ & 182.0 & 147.9 & 300.0 & 300.0 & 0 \\
\hline & & 銅 & 5.80 & 19.02 & 16.87 & 9.88 & 0.11 \\
\hline & & 銀 & 0.74 & 1.33 & 0.45 & 0.18 & 0.04 \\
\hline
\end{tabular}

\section{表 4 分析に用いた設定値}

\begin{tabular}{|c|c|c|c|c|}
\hline プロセス & $\begin{array}{l}\text { 該当 } \\
\text { 工程 }\end{array}$ & 内容 & 仮定值 & 単位 \\
\hline \multirow{5}{*}{ 輸送 } & \multirow{5}{*}{ A, B, C, D } & 輸送距離（パネル処理業者への輸送時） & 100 & $\mathrm{~km}$ \\
\hline & & 輸送距離（上記以外の輸送時） & 50 & $\mathrm{~km}$ \\
\hline & & 輸送トラックの積載重量 & 4 & $\mathrm{t} /$ 台 \\
\hline & & \begin{tabular}{|l|} 
輸送トラックの積載率 \\
(パネル処理業者への輸送時)
\end{tabular} & 100 & $\%$ \\
\hline & & $\begin{array}{l}\text { 輸送トラックの積載率 } \\
\text { (上記以外の輸送時) }\end{array}$ & 75 & $\%$ \\
\hline 手解体 & $A, B$ & $\begin{array}{l}\text { ジャンクションボックスに含まれる } \\
\text { ハーネス量 }(\text { 重量\%) }\end{array}$ & 50 & $\%$ \\
\hline 乾式製錬 & A & 被溶融物のスラグ化時の重量（重量\%) & 100 & $\%$ \\
\hline
\end{tabular}

\section{表 5 原単位に関する設定値}

\begin{tabular}{|c|c|c|c|c|c|}
\hline プロセス & $\begin{array}{l}\text { 該当 } \\
\text { 工程 }\end{array}$ & 内容 & 使用原単位 & 排出量 & 単位 \\
\hline \multirow{2}{*}{ 輸送 } & A, C & $\begin{array}{l}\mathrm{PV} \text { パネル处理業者 } \\
\text { への輸送時 } \mathrm{CO}_{2} \text { 排出量 }\end{array}$ & $\begin{array}{l}\text { トラック輸送 (4t車: } \\
\text { 積載率 } 100 \%) \text { C } 2 \text { 排出量 }\end{array}$ & 0.185 & $\begin{array}{c}\mathrm{kg}-\mathrm{CO} 2 \\
/ \mathrm{tkm}\end{array}$ \\
\hline & $\mathrm{B}, \mathrm{C}$ & $\begin{array}{l}\text { 上記以外の輸送時の } \\
\mathrm{CO} 2 \text { 排出量 }\end{array}$ & $\begin{array}{l}\text { トラック輸送 (4t 車: } \\
\text { 積載率 } 75 \% \text { C } 2 \text { 排出量 }\end{array}$ & 0.234 & $\begin{array}{c}\mathrm{kg}-\mathrm{CO} 2 \\
/ \mathrm{tkm}\end{array}$ \\
\hline $\begin{array}{l}\text { 乾式製錬 } \\
\text { (スラグ化) }\end{array}$ & A & $\begin{array}{l}\text { 処理物 } 1 \mathrm{~kg} \text { 溶融時の } \\
\mathrm{CO}_{2} \text { 排出量 }\end{array}$ & $\begin{array}{l}\text { アルミスクラップ1 kg溶融時 } \\
\text { のCO2排出量 }{ }^{10)}\end{array}$ & 0.287 & $\begin{array}{c}\mathrm{kg}-\mathrm{CO}_{2} \\
/ \mathrm{kg}\end{array}$ \\
\hline $\begin{array}{l}\text { 乾式製鍊 } \\
\text { (銀再生) }\end{array}$ & C & $\begin{array}{l}\text { 製錬処理により銀 } 1 \mathrm{~kg} \text { を再 } \\
\text { 生する際のCO2排出量 }\end{array}$ & $\begin{array}{l}\text { 銅乾式製鍊の際, 併産される } \\
\text { 銀1/k地たりのCO2排出量 }{ }^{11)}\end{array}$ & 14.8 & $\begin{array}{c}\mathrm{kg}-\mathrm{CO}_{2} \\
/ \mathrm{kg}\end{array}$ \\
\hline
\end{tabular}

\section{表 6 機器仕様に関する設定値}

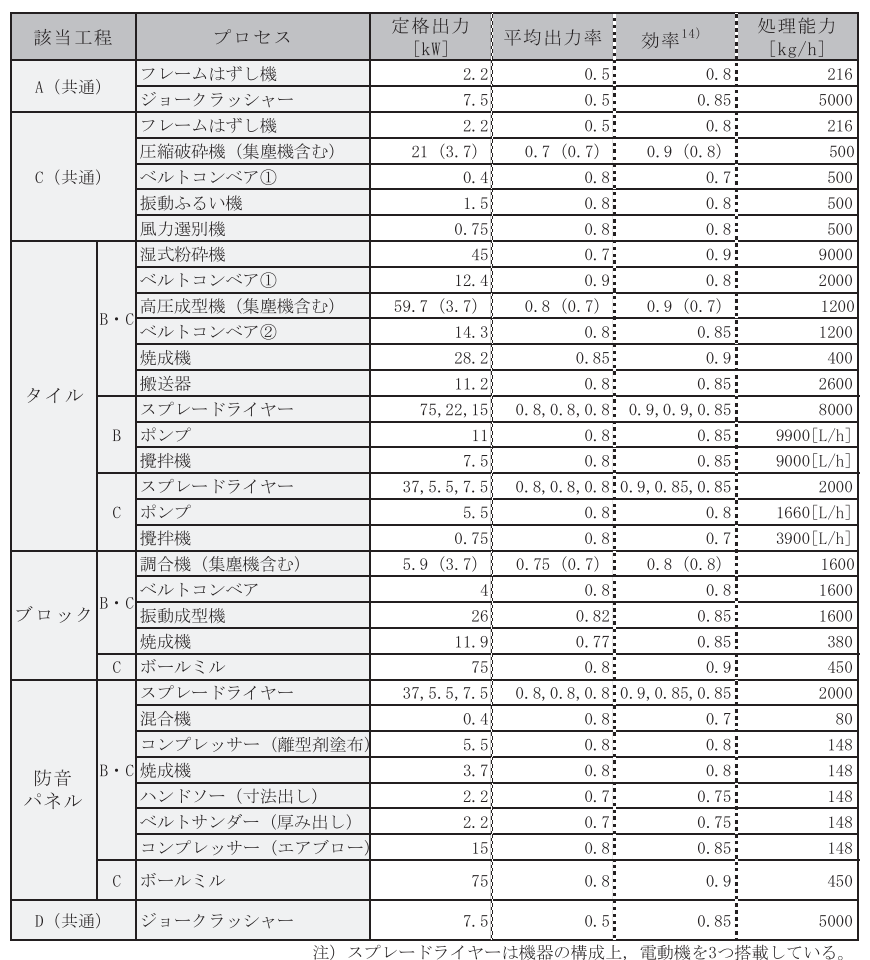


工程 $\mathrm{A}$ では排出量の合計は $324.5 \mathrm{kgCO}_{2} / \mathrm{t}^{\prime}$ となった。そのうち 224. $6 \mathrm{~kg}-\mathrm{CO}_{2}$ はスラグ化時の乾式製鍊プロセスにおける排出量であ り，工程全体のおよそ 7 割を占めた。次いで，大きかったのはアル ミ再生プロセスにおける $58.0 \mathrm{kgCO}_{2} / \mathrm{t}^{\prime}$ であった。工程 B では排出量 の合計は $890.9 \mathrm{kgCO}_{2} / \mathrm{t}^{\prime}$ となった。そのうち $626.2 \mathrm{kgCO}_{2} / \mathrm{t}^{\prime}$ はタイ ル焼成プロセスでの LPG 利用による排出量であり，このプロセスで 工程全体のおよそ 7 割を占めることが判明した。次いで，大きかっ たのはスプレードライヤープロセスにおける A 重油利用による排出 量で $178.1 \mathrm{kgCO}_{2} / \mathrm{t}^{\prime}$ であった。工程 $\mathrm{C}$ では排出量の合計は 808.6 $\mathrm{kgCO}_{2} / \mathrm{t}^{\prime}$ となった。そのうち $417.4 \mathrm{kgCO}_{2} / \mathrm{t}^{\prime}$ はタイル焼成プロセスに おける $\mathrm{LPG}$ 利用による排出であるが，工程 B の同プロセスと比較す ると, $208.7 \mathrm{kgCO}_{2} / \mathrm{t}^{\prime}$ の低減がなされている。これは, 天然原料に 替えてガラスカレットを用いたことによる燃料削減効果によるもの である。また, PV パネルからガラスカレットを製造するまで（表 9 中, 管理型埋立まで）の排出量の合計は $104.0 \mathrm{kgCO}_{2} / \mathrm{t}^{\prime}$ となり, 工程 C の排出量の合計に対し, 1 割程度の值に留まった。工程 D では排 出量の合計は $5.8 \mathrm{kgCO}_{2} / \mathrm{t}^{\prime}$ であり, 全体への影響は小さい。

\section{3. $2 \mathrm{PV}$ パネル種類, リサイクル製品別 $\mathrm{CO}_{2}$ 削減効果}

表 11 に $\mathrm{PV}$ パネル種類, 再資源化製品ごとの工程別 $\mathrm{CO}_{2}$ 排出量,

\section{表 7 タイル製造時のプロセス別 $\mathrm{CO}_{2}$ 排出量（工程 $\mathrm{A}$ ）}

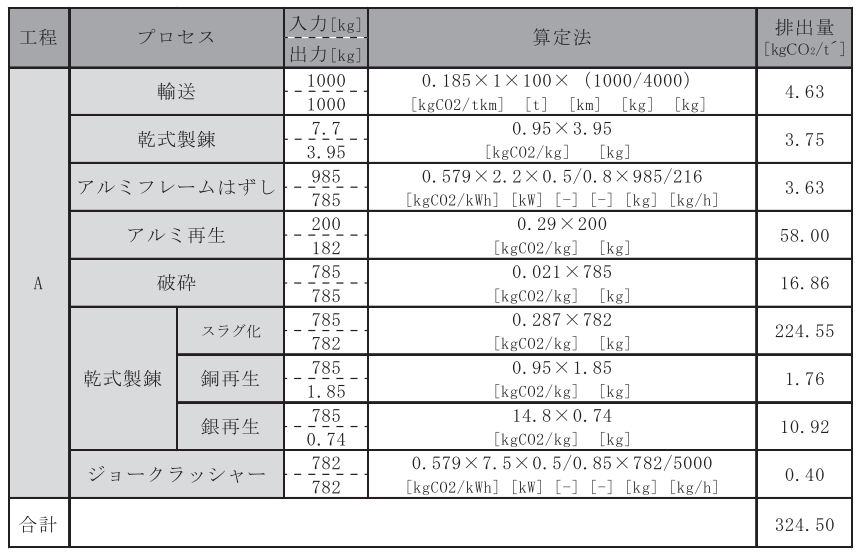

表 8 タイル製造時のプロセス別 $\mathrm{CO}_{2}$ 排出量（工程 $\mathrm{B}$ )

\begin{tabular}{|c|c|c|c|c|c|}
\hline 工程 & \multicolumn{2}{|c|}{ プロセス } & 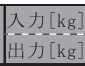 & 算定法 & $\begin{array}{r}\begin{array}{r}\text { 排出量 } \\
{\left[\mathrm{kgCO}_{2} / \mathrm{t}^{-}\right.}\end{array} \\
\end{array}$ \\
\hline \multirow{15}{*}{ B } & \multicolumn{2}{|c|}{ 長石採取～製錬 } & $-\frac{438}{438}-$ & $\begin{array}{r}0.0011 \times 438 \\
{[\mathrm{kgCO} / \mathrm{kg}][\mathrm{kg}]}\end{array}$ & 0.48 \\
\hline & \multicolumn{2}{|c|}{ 輸送 } & $-438-$ & $\begin{array}{c}0.234 \times 1 \times 50 \times(438 / 4000 \times 0.75) \\
{[\mathrm{kgCO} 2 / \mathrm{tkm}][\mathrm{t}][\mathrm{km}][\mathrm{kg}][\mathrm{kg}][-]}\end{array}$ & 1.71 \\
\hline & \multicolumn{2}{|c|}{ 湿式粉挽 } & $-\frac{438}{1314}-$ & $\begin{array}{c}0.579 \times 45 \times 0.7 / 0.9 \times 1314 / 9000 \\
{[\mathrm{kgCO} 2 / \mathrm{kW}][\mathrm{kW}][-][-][\mathrm{kg}][\mathrm{kg} / \mathrm{h}]}\end{array}$ & 2.96 \\
\hline & \multicolumn{2}{|c|}{ ポンプ } & $-\frac{1}{13} 314$ & $\begin{array}{c}0.579 \times 11 \times 0.8 / 0.85 \times 864 / 9900 \\
{[\mathrm{kgCO} 2 / \mathrm{kWh}][\mathrm{kW}][-][-][\mathrm{L}][\mathrm{L} / \mathrm{h}]}\end{array}$ & 0.52 \\
\hline & \multicolumn{2}{|c|}{ 擋汼 } & $-\frac{1314}{1314}$ & $\begin{array}{c}0.579 \times 7.5 \times 0.8 / 0.85 \times 864 / 9000 \\
{[\mathrm{kgCO} 2 / \mathrm{kWh}][\mathrm{kW}][-][-][\mathrm{L}][\mathrm{L} / \mathrm{h}]}\end{array}$ & 0.39 \\
\hline & \multirow[t]{2}{*}{$\begin{array}{l}\text { スプレー } \\
\text { ドライヤー }\end{array}$} & 電力使用 & $\begin{array}{c}1314 \\
---- \\
851.5 \\
\end{array}$ & $\begin{array}{c}0.579 \times(75 / 0.9+22 / 0.9+15 / 0.85) \\
\times 0.8 \times 1314 / 8000 \\
[\mathrm{kgCO} / \mathrm{kWh}][\mathrm{kW}][-] \mathrm{kww}][-] \mathrm{kww}][-] \\
[-][\mathrm{kg}] \mathrm{kg} / \mathrm{h}]\end{array}$ & 9. 54 \\
\hline & & 燃料使用 & $\begin{array}{l}1314 \\
851.5 \\
851.5\end{array}$ & $\begin{array}{c}2.71 \times 400 \times 1314 / 8000 \\
{[\mathrm{kgCO} 2 / \mathrm{L}][\mathrm{L} / \mathrm{h}][\mathrm{kg}][\mathrm{kg} / \mathrm{h}]}\end{array}$ & 178.1 \\
\hline & \multicolumn{2}{|c|}{ ベルトコンベア } & $\begin{array}{l}851.5 \\
851.5\end{array}$ & $\begin{array}{c}0.579 \times 12.4 \times 0.9 / 0.8 \times 851.5 / 2000 \\
{[\mathrm{kgCO} 2 / \mathrm{kWh}][\mathrm{kW}][-][-][\mathrm{kg}][\mathrm{kg} / \mathrm{h}]}\end{array}$ & 3.44 \\
\hline & \multicolumn{2}{|c|}{ 輸送 } & $-\frac{851}{851.5} \cdot \frac{5}{5}$ & $\begin{array}{c}0.234 \times 1 \times 50 \times(851.5 / 4000 \times 0.75) \\
{[\mathrm{kgCO} 2 / \mathrm{kmm}][\mathrm{t}][\mathrm{km}][\mathrm{kg}][\mathrm{kg}][-]}\end{array}$ & 3.32 \\
\hline & \multirow{2}{*}{ 高压成型 } & 成型機 & $\begin{array}{l}851.5 \\
-851.5 \\
\end{array}$ & $\begin{array}{c}0.579 \times 59.7 \times 0.8 / 0.9 \times 851.5 / 1200 \\
{[\mathrm{kgCO} 2 / \mathrm{kWh}][\mathrm{kW}][-][-][\mathrm{kg}][\mathrm{kg} / \mathrm{h}]}\end{array}$ & 21.8 \\
\hline & & 集塵機 & -851.5 & $\begin{array}{c}0.579 \times 3.7 \times 0.7 / 0.8 \times 851.5 / 1200 \\
{[\mathrm{kgCO} 2 / \mathrm{kWh}][\mathrm{kW}][-][-][\mathrm{kg}][\mathrm{kg} / \mathrm{h}]}\end{array}$ & 1.33 \\
\hline & \multicolumn{2}{|c|}{ ベルトコンベア } & $\begin{array}{l}851.5 \\
851.5 \\
-5\end{array}$ & $\begin{array}{c}0.579 \times 14.3 \times 0.8 / 0.85 \times 851.5 / 1200 \\
{[\mathrm{kgCO} 2 / \mathrm{kWh}][\mathrm{kW}][-][-][\mathrm{kg}][\mathrm{kg} / \mathrm{h}]}\end{array}$ & 5.53 \\
\hline & \multirow{2}{*}{ 焼成 } & 電力使用 & $\begin{array}{l}851.5 \\
788.4 \\
\end{array}$ & $\begin{array}{c}0.579 \times 28.2 \times 0.85 / 0.9 \times 851.5 / 400 \\
[\mathrm{kgCO} 2 / \mathrm{kWh}][\mathrm{kW}][-][-] \mathrm{kg}][\mathrm{kg} / \mathrm{h}]\end{array}$ & 32.83 \\
\hline & & 燃料使用 & $-\frac{851.5}{788.4}$ & $\begin{array}{l}3.00 \times 98.05 \times 851.5 / 400 \\
{[\mathrm{kgCO} 2 / \mathrm{kg}][\mathrm{kg} / \mathrm{h}][\mathrm{kg}][\mathrm{kg} / \mathrm{h}]}\end{array}$ & 626.17 \\
\hline & \multicolumn{2}{|c|}{ 搬送 } & $\begin{aligned} & 788-4 \\
& 788.4 \\
&\end{aligned}$ & $\begin{array}{c}0.579 \times 11.2 \times 0.8 / 0.85 \times 788.4 / 2600 \\
{[\mathrm{kgCO} 2 / \mathrm{kWh}][\mathrm{kW}][-][-][\mathrm{kg}][\mathrm{kg} / \mathrm{h}]} \\
\end{array}$ & 1.85 \\
\hline 合計 & & 889.91 \\
\hline
\end{tabular}

及び $\mathrm{CO}_{2}$ 削減量を示す。タイルへの再資源化時には, 310 $442 \mathrm{kgCO}_{2} / \mathrm{t}^{\prime}$ の $\mathrm{CO}_{2}$ 削減効果が得られた。最大となるのは CIGS 系 PV パネルを処理した場合であり, 次いで単結晶系, 多結晶系, 薄膜系 の順となった。本検討では, タイル焼成プロセスにおける $\mathrm{CO}_{2}$ 排出 量が大きいが, 薄膜系 PV パネルのようなガラス含有率の比較的小さ いものは, 焼成プロセスでの処理量が他の PV パネルより小さく, 工 程 $\mathrm{B}, \mathrm{C}$ における $\mathrm{CO}_{2}$ 排出量は他の $\mathrm{PV}$ パネルの場合より小さくなった。 ブロックと防音パネルへのリサイクル時に関しても，142〜 $238 \mathrm{kgCO}_{2} / \mathrm{t}^{\prime}$ の $\mathrm{CO}_{2}$ 削減効果が得られることが分かった。ブロックは ガラス使用率が $10 \%$ と低いものであり，1 t の PV パネルから生産さ れる製品の量はタイルと比較して大きくなる(表 3 を参照)。そのた め, ブロック焼成プロセスでの処理量が増えることで $\mathrm{CO}_{2}$ 排出量が 大きくなり, タイル製造時に比べ工程 B と C の值が大きくなってい る。逆に防音パネルに関してはガラス使用率が $95.2 \%$ と高く, 焼成 に化石燃料を用いないため工程 B と C の值は他の製品に比べ小さく

\section{表 9 タイル製造時のプロセス別 $\mathrm{CO}_{2}$ 排出量（工程 C)}

\begin{tabular}{|c|c|c|c|c|c|}
\hline 工程 & \multicolumn{2}{|c|}{ プロセス } & \begin{tabular}{|l|} 
入力 $[\mathrm{kg}]$ \\
出力 $[\mathrm{kg}]$ \\
\end{tabular} & 算定法 & $\begin{array}{c}\text { 排出量 } \\
{\left[\mathrm{kgCO}_{2} / \mathrm{t}^{t}\right]}\end{array}$ \\
\hline & \multicolumn{2}{|c|}{ 輸送 } & $-\frac{1000}{1000}-$ & 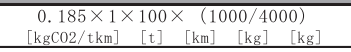 & 4.63 \\
\hline & \multicolumn{2}{|c|}{ 乾式製鍊 } & $-\frac{7}{3} \div \frac{7}{95}-$ & $\begin{array}{c}0.95 \times 3.95 \\
{[\mathrm{kgC0} 2 / \mathrm{kg}] \quad[\mathrm{kg}]}\end{array}$ & 3.75 \\
\hline & \multicolumn{2}{|c|}{ アルミフレームはずし } & $-\frac{985}{785}-$ & $\begin{array}{r}0.579 \times 2.2 \times 0.5 / 0.8 \times 985 / 216 \\
{[\mathrm{kgCO} / \mathrm{kWh}][\mathrm{kW}][-][-][\mathrm{kg}][\mathrm{kg} / \mathrm{h}]}\end{array}$ & 3.63 \\
\hline & \multicolumn{2}{|c|}{ アルミ再生 } & $-\frac{200-}{182}$ & $\begin{array}{c}0.29 \times 200 \\
{[\mathrm{kgCO} 2 / \mathrm{kg}] \quad[\mathrm{kg}]}\end{array}$ & 58.00 \\
\hline & \multirow{2}{*}{ 圧縮破砕 } & 破砕機 & \begin{tabular}{|l|l|}
-785 \\
$453.9-$ \\
\end{tabular} & $\begin{array}{c}0.579 \times 21 \times 0.7 / 0.9 \times 785 / 500 \\
{[\mathrm{kgCO} / \mathrm{kWh}][\mathrm{kW}][-][-][\mathrm{kg}][\mathrm{kg} / \mathrm{h}]}\end{array}$ & 14.85 \\
\hline & & 集塺機 & \begin{tabular}{|l|l|}
785 \\
45 & -9 \\
\end{tabular} & $\begin{array}{c}0.579 \times 3.7 \times 0.7 / 0.8 \times 785 / 500 \\
{[\mathrm{kgCO2} / \mathrm{kWh}][\mathrm{kWW}][-][-][\mathrm{kg}][\mathrm{kg} / \mathrm{h}]}\end{array}$ & 2.94 \\
\hline & \multirow{2}{*}{ 乾式製鍊 } & 銅再生 & \begin{tabular}{|l|l|}
346.6 \\
1.85 \\
\end{tabular} & $\begin{array}{c}0.95 \times 1.85 \\
{[\mathrm{kgCO} / \mathrm{kg}] \quad[\mathrm{kg}]}\end{array}$ & 1.76 \\
\hline & & 銀再生 & $\begin{aligned} 346.6 \\
0.74 \\
\end{aligned}$ & $\begin{array}{c}14.8 \times 0.74 \\
{[\mathrm{kgC0} 2 / \mathrm{kg}] \quad[\mathrm{kg}]}\end{array}$ & 10.92 \\
\hline & \multicolumn{2}{|c|}{ ベルトコンベア } & \begin{tabular}{|l|l|}
453 & 3.9 \\
453.9 & - \\
\end{tabular} & $\begin{array}{l}0.579 \times 0.4 \times 0.8 / 0.7 \times 1.57 \\
{[\mathrm{kgC02} / \mathrm{kWh}][\mathrm{kW}][-][-][\mathrm{h}]}\end{array}$ & 0.42 \\
\hline & \multicolumn{2}{|c|}{ 振動ふるい } & $\begin{aligned}-453.9 \\
-238.5 \\
\end{aligned}$ & $\begin{array}{l}0.579 \times 1.5 \times 0.8 / 0.8 \times 1.57 \\
{[\mathrm{kgCO} / \mathrm{kWh}][\mathrm{kW}][-][-][\mathrm{h}]}\end{array}$ & 1.36 \\
\hline & \multicolumn{2}{|c|}{ ベルトコンベア } & \begin{tabular}{|l|l|}
238 \\
238.5 \\
\end{tabular} & $\begin{array}{l}0.579 \times 0.4 \times 0.8 / 0.7 \times 1.57 \\
{[\mathrm{kgCO2} / \mathrm{kWh}][\mathrm{kW}][-][-][\mathrm{h}]}\end{array}$ & 0.42 \\
\hline & \multicolumn{2}{|c|}{ 風力選別 } & \begin{tabular}{|l|l|}
238 & -5 \\
223.1 & \\
\end{tabular} & $\begin{array}{l}0.579 \times 0.75 \times 0.8 / 0.8 \times 1.57 \\
{[\mathrm{kgCOC2} / \mathrm{kWh}][\mathrm{kW}][-][-][\mathrm{h}]} \\
\end{array}$ & 0.68 \\
\hline & \multicolumn{2}{|c|}{ 輸送 } & $-\frac{15 .}{15 .} \frac{4}{4}-$ & 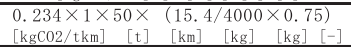 & 0.059 \\
\hline & \multicolumn{2}{|c|}{ 管理型埋立 } & $-\frac{15}{-}-\frac{4}{-}-$ & $\begin{array}{c}0.038 \times 15.4 \\
{[\mathrm{kgCOC2} / \mathrm{kg}][\mathrm{kg}]}\end{array}$ & 0.57 \\
\hline c & \multicolumn{2}{|c|}{ 輸送 } & $-4 \frac{33}{438}-1$ & 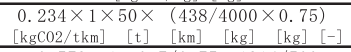 & 1.71 \\
\hline & \multicolumn{2}{|c|}{ 湿式粉砕 } & \begin{tabular}{|l|l|}
$-\frac{43}{3} 8$ \\
1314 \\
\end{tabular} & $\begin{array}{c}0.579 \times 1 \times 0.7 / 0.75 \times 1314 / 500 \\
{[\mathrm{kgC02} / \mathrm{kWh}][\mathrm{kW}][-][-][\mathrm{kg}][\mathrm{kg} / \mathrm{h}]}\end{array}$ & 1.42 \\
\hline & \multicolumn{2}{|c|}{ ポンプ } & \begin{tabular}{|l|l|}
$-\frac{13}{3} 14$ & $-14-$ \\
& 1314 \\
\end{tabular} & $\begin{array}{l}0.579 \times 5.5 \times 0.8 / 0.8 \times 864 / 3900 \\
{[\mathrm{kgC02} / \mathrm{kWh}][\mathrm{kW}][-][-][\mathrm{L}][\mathrm{L} / \mathrm{h}]}\end{array}$ & 0.71 \\
\hline & \multicolumn{2}{|c|}{ 摚汼 } & $-\frac{1314}{1314}-$ & $\begin{array}{l}0.579 \times 0.75 \times 0.8 / 0.8 \times 864 / 1660 \\
{[\mathrm{kgCO} 2 / \mathrm{kWh}][\mathrm{kW}][-][-][\mathrm{L}][\mathrm{LL} / \mathrm{h}]}\end{array}$ & 0.26 \\
\hline & \multirow[t]{2}{*}{$\begin{array}{l}\text { スプレー } \\
\text { ドライヤー }\end{array}$} & 電力使用 & \begin{tabular}{|c|}
1314 \\
851.5 \\
\end{tabular} & $\begin{array}{r}0.579 \times(37 / 0.9+5.5 / 0.85+17.5 / 0.85) \\
\times 0.8 \times 1314 / 2000 \\
{[\mathrm{kgC02} / \mathrm{kWh}][\mathrm{kW}][-][\mathrm{kW}][-] \quad[\mathrm{kW}] \quad[-]} \\
{[-][\mathrm{kg}][\mathrm{kg} / \mathrm{h}]}\end{array}$ & 17.17 \\
\hline & & 燃料使用 & \begin{tabular}{|l|l|} 
& 1314 \\
851.5 & - \\
\end{tabular} & 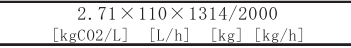 & 195.85 \\
\hline & \multicolumn{2}{|c|}{ ベルトコンベア } & $\begin{aligned} 851.5 \\
851.5 \\
\end{aligned}$ & $\begin{array}{l}0.579 \times 12.4 \times 0.9 / 0.8 \times 851.5 / 2000 \\
{[\mathrm{kgC02} / \mathrm{kWh}][\mathrm{kW}][-][-][\mathrm{kg}][\mathrm{kg} / \mathrm{h}]}\end{array}$ & 3.44 \\
\hline & \multicolumn{2}{|c|}{ 輸送 } & $-\frac{851}{85} \cdot \frac{5}{5}$ & $\begin{array}{ccc}0.234 \times 1 \times 50 \times & (851.5 / 4000 \times 0.75) \\
{[\mathrm{kgC02} / \mathrm{tkm}] \quad[\mathrm{t}]} & {[\mathrm{km}] \quad[\mathrm{kg}] \quad[\mathrm{kg}] \quad[-]}\end{array}$ & 3.32 \\
\hline & \multirow{2}{*}{ 高圧成型 } & 成型機 & $\begin{aligned} 851.5 \\
851.5 \\
5\end{aligned}$ & $\begin{array}{l}0.579 \times 59.7 \times 0.8 / 0.9 \times 851.5 / 1200 \\
{[\mathrm{kgCO} / \mathrm{kWh}][\mathrm{kW}][-][-][\mathrm{kg}][\mathrm{kg} / \mathrm{h}]}\end{array}$ & 21.8 \\
\hline & & 集塵機 & \begin{tabular}{|l|l}
$851 \cdot 5$ \\
-851.5 \\
\end{tabular} & $\begin{array}{l}0.579 \times 3.7 \times 0.7 / 0.8 \times 851.5 / 1200 \\
{[\mathrm{kgC02} / \mathrm{kWh}][\mathrm{kW}][-][-][\mathrm{kg}][\mathrm{kg} / \mathrm{h}]}\end{array}$ & 1.33 \\
\hline & \multicolumn{2}{|c|}{ ベルトコンベア } & $\begin{aligned} 851 \cdot 5 \\
851.5 \\
\end{aligned}$ & $\begin{array}{l}0.579 \times 14.3 \times 0.8 / 0.85 \times 851.5 / 1200 \\
{[\mathrm{kgC02} / \mathrm{kWh}][\mathrm{kW}][-][-][\mathrm{kg}][\mathrm{kg} / \mathrm{h}]}\end{array}$ & 5.53 \\
\hline & \multirow{2}{*}{ 焼成 } & 電力使用 & \begin{tabular}{|l|l|}
-851.5 \\
788.4 \\
\end{tabular} & $\begin{array}{l}0.579 \times 28.2 \times 0.85 / 0.9 \times 851.5 / 400 \\
{[\mathrm{kgC02} / \mathrm{kWh}][\mathrm{kWW}][-][-][\mathrm{kg}][\mathrm{kg} / \mathrm{h}]}\end{array}$ & 32.83 \\
\hline & & 燃料使用 & $\begin{aligned} 851.5 \\
788.4 \\
\end{aligned}$ & $\begin{array}{c}3.00 \times 65.4 \times 851.5 / 400 \\
{[\mathrm{kgCO} / \mathrm{kg}][\mathrm{kg} / \mathrm{h}] \quad[\mathrm{kg}][\mathrm{kg} / \mathrm{h}]}\end{array}$ & 417.44 \\
\hline & \multicolumn{2}{|c|}{ 搬送 } & \begin{tabular}{|l|l|}
788.4 \\
788.4 \\
\end{tabular} & $\begin{array}{c}0.579 \times 11.2 \times 0.8 / 0.85 \times 788.4 / 2600 \\
{[\mathrm{kgC02} / \mathrm{kWh}][\mathrm{kW}][-][-][\mathrm{kg}][\mathrm{kg} / \mathrm{h}]}\end{array}$ & 1.85 \\
\hline 合 & & & & & 808.63 \\
\hline
\end{tabular}

表 10 タイル製造時のプロセス別 $\mathrm{CO}_{2}$ 排出量（工程 D)

\begin{tabular}{|c|c|c|c|c|}
\hline 工程 & プロセス & \begin{tabular}{|l|} 
入力 $[\mathrm{kg}]$ \\
出力 $[\mathrm{kg}]$ \\
\end{tabular} & 算定法 & $\begin{array}{l}\text { 排出量 } \\
{\left[\mathrm{kgCO}_{2} / \mathrm{t}^{-}\right]}\end{array}$ \\
\hline \multirow{2}{*}{ D } & 採石 & $-\frac{782}{782}-$ & $\begin{array}{c}0.0069 \times 782 \\
{[\mathrm{kgCO} / \mathrm{kg}] \quad[\mathrm{kg}]}\end{array}$ & 5.43 \\
\hline & 破砕 & $-\frac{782}{782-}$ & $\begin{array}{c}0.579 \times 7.5 \times 0.5 / 0.85 \times 782 / 5000 \\
{[\mathrm{kgC02} / \mathrm{kWh}][\mathrm{kW}][-][-][\mathrm{kg}][\mathrm{kg} / \mathrm{h}]}\end{array}$ & 0.40 \\
\hline 合計 & & & & 5.83 \\
\hline
\end{tabular}


なった。

ブロックと防音パネルの場合, 工程 B と C において製品の原料は 共にガラスである（B は既存ガラスカレット， C は PV パネルから抽 出したガラスカレット)。そのため, 両製品とも工程 B とCの製品製 造部分において $\mathrm{CO}_{2}$ 排出量に差が生じない。依って，ブロックと防 音パネルについては $\mathrm{CO}_{2}$ 削減効果 $([\mathrm{A}+\mathrm{B}]-[\mathrm{C}+\mathrm{D}])$ が同じ值となった。

また，ガラス再資源化製品 $1 \mathrm{~kg}$ 当たりのC02 削減効果はタイルの 場合で $0.51 \sim 0.61$ ，ブロックで $0.04 \sim 0.06$ ，防音パネルで $0.38 \sim$ $0.57 \mathrm{kgCO}_{2} / \mathrm{kg}$ となった。

図 4 に再資源化製品, PV パネル種類ごとの $\mathrm{CO}_{2}$ 排出量の内訳を示 す。いずれの製品化の場合でも，提案工程では乾式製鍊プロセスが 無くなることで, 現状工程との $\mathrm{CO}_{2}$ 削減量の差が大きくなっている。 タイルへの再資源化時の $\mathrm{CO}_{2}$ 排出量の内訳に着目すると, タイル焼 成プロセスでの燃料削減効果が結果に影響を及ぼし, $\mathrm{CO}_{2}$ 削減に大き く寄与していることが分かる。今回の分析では，ガラスカレット利 用による燃料削減効果が大きいため, ガラスの含有量の大きい PV パネルほど大きな $\mathrm{CO}_{2}$ 削減効果が見込まれるが，結果としては最も ガラス含有率の大きい単結晶系より CIGS 系のほうが大きい削減効 果を得た。これは今回，取り扱った CIGS 系 PV パネルがアルミフレ 一ムを含まないものであったためである。他の種類の PV パネルの場 合, 工程 A のスラグ化に関する乾式製錬プロセスでの処理量は PV パネル $1 \mathrm{t}$ からアルミフレームを163〜330kg 取り除いたものになる が，CIGS 系 PV パネルに関してはアルミフレーム除去による乾式製 鍊プロセスでの処理量の減少は無い。そのため, 図 4 に示寸ように,
CIGS 系 PV パネルの乾式製鍊プロセスでの $\mathrm{CO}_{2}$ 排出量は他の PV パネ ルの場合と比較して大きいものとなっている。

現状工程に対する提案工程の $\mathrm{CO}_{2}$ 削減率については防音パネル の再資源化時で $37 \sim 61 \%$ ，タイルで $31 \sim 39 \%$, ブロックで $11 \sim 16 \%$ となった。 $\mathrm{CO}_{2}$ 削減率という点では, ガラス使用率の高い製品へのリ サイクルが有利となる。

\section{3 埋立処理をした場合との比較}

工程 AのPV パネルの処理方法を埋立処理とした場合についても分 析を実施した。図 1 における, 工程 A，B をそれぞれ図 5 に示した工 程に置き換え, 分析を行った。なお, この分析については工程 $\mathrm{A} に$ おいて路盤材は生じないため, 工程 D のプロセスは発生しない。ま た，本検討では工程 A で埋立処理を行うことで製鍊スラグ化プロセ スにおける副産物である再生銀，銅は回収できない。そこで，アウ トプットを揃えるために，工程 B に天然原料から銀，銅を製造する プロセスを加えている。

図 6 に工程 A を埋立処理とした場合のリサイクル製品ごとの各工 程における $\mathrm{CO}_{2}$ 排出量, 最終的な $\mathrm{CO}_{2}$ 削減効果, 及び現状工程と提案 工程の $\mathrm{CO}_{2}$ 排出量の内訳を示す。なお，ここでは単結晶系 $\mathrm{PV}$ パネル を処理した場合の結果を記載する。

現状工程を PV パネルを溶融スラグ化し路盤材として利用すると した場合の結果と比較して,埋立処理とした場合は, スラグ化に関す る乾式製錬プロセスが無くなったことでいずれの製品化に関しても カテゴリ $\mathrm{A} の \mathrm{CO}_{2}$ 排出量が小さくなっている。その結果, 提案工程と の排出量の差が小さくなり, $\mathrm{CO}_{2}$ 削減効果も小さくなっているが, タ

表 11 各工程の $\mathrm{CO}_{2}$ 排出量算定結果

\begin{tabular}{|c|c|c|c|c|c|c|c|c|c|c|c|c|c|c|c|}
\hline & \multicolumn{5}{|c|}{ タイルへのリサイクル時 } & \multicolumn{5}{|c|}{ ブロックへのリサイクル時 } & \multicolumn{5}{|c|}{ 防音パネルへのリサイクル時 } \\
\hline 工程 & 単結晶系 & 多結晶系 & $\begin{array}{l}\begin{array}{l}\text { 薄膜系 } \\
(\text { (コルシ十) }\end{array} \\
\end{array}$ & $\begin{array}{l}\text { 薄膜系 } \\
(y-\text { 石石 } \\
\end{array}$ & CIGS系 & 単結晶系 & 多結晶系 & $\begin{array}{l}\text { 薄膜系 } \\
(\text { アルシナ) }\end{array}$ & $\begin{array}{c}\text { 薄膜系 } \\
(y-タ \text { 名石 })\end{array}$ & CIGS系 & 単結晶系 & 多結晶系 & $\begin{array}{l}\begin{array}{l}\text { 薄膜系 } \\
(\text { (丁ルミ゙) }\end{array} \\
\end{array}$ & $\begin{array}{c}\begin{array}{c}\text { 薄膜系 } \\
\text { (-夕夕石灰 })\end{array} \\
\end{array}$ & CIGS系 \\
\hline $\mathrm{A}$ & 324.5 & 341.6 & 320.9 & 312.3 & 314.2 & 324.5 & 341.6 & 320.9 & 312.3 & 314.2 & 324.5 & 341.6 & 320.9 & 312.3 & 314.2 \\
\hline $\mathrm{B}$ & 889.9 & 761.9 & 669.9 & 669.9 & 812.7 & 1298.6 & 1111.8 & 977.5 & 977.5 & 1185.9 & 83.1 & 71.5 & 63.2 & 63.2 & 76.1 \\
\hline $\mathrm{C}$ & 808.6 & 718.0 & 676.3 & 665.6 & 677.9 & 1440.1 & 1258.9 & 1151.8 & 1141.2 & 1254.8 & 224.7 & 218.6 & 237.5 & 226.9 & 145.0 \\
\hline $\mathrm{D}$ & 5.8 & 6.0 & 4.7 & 4.7 & 7.4 & 5.8 & 6.0 & 4.7 & 4.7 & 7.4 & 5.8 & 6.0 & 4.7 & 4.7 & 7.4 \\
\hline $\begin{array}{c}\mathrm{CO}_{2} \mathrm{ll}_{1} \text { 隇量 } \\
(\mathrm{A}+\mathrm{B})-(\mathrm{C}+\mathrm{D})\end{array}$ & 400.0 & 379.5 & 309.8 & 311.8 & 441.6 & 177.1 & 188.6 & 141.9 & 143.9 & 237.9 & 177.1 & 188.6 & 141.9 & 143.9 & 237.9 \\
\hline $\begin{array}{l}\text { 再資源化製品 } 1 \mathrm{~kg} \\
\text { 当たり }\end{array}$ & 0.507 & 0.562 & 0.522 & 0.525 & 0.613 & 0.040 & 0.050 & 0.043 & 0.044 & 0.059 & 0.384 & 0.478 & 0.409 & 0.414 & 0.565 \\
\hline
\end{tabular}

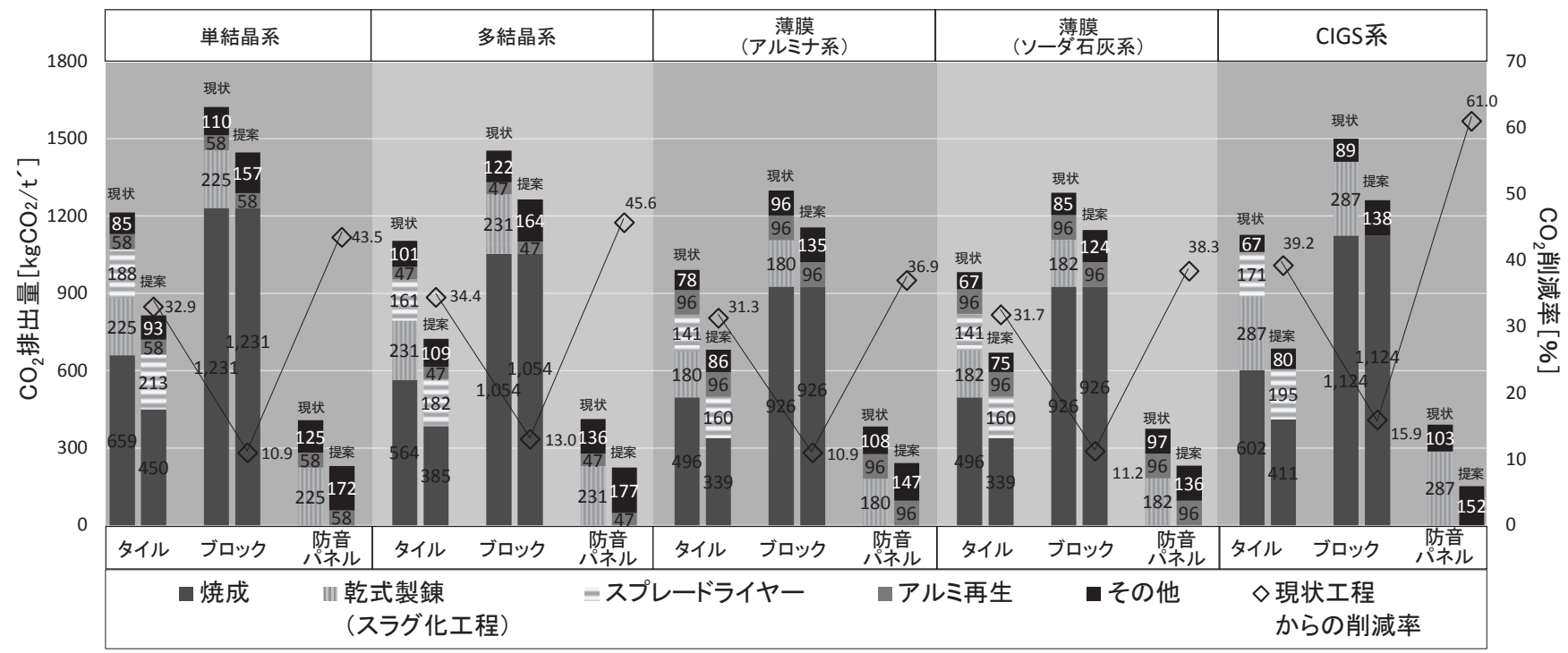

図 4 再資源化実施時の $\mathrm{CO}_{2}$ 排出量内訳 
イルへの再資源化に関しては $227 \mathrm{kgCO}_{2} / \mathrm{t}^{\prime}$ の削減量を得た。また, ブ ロック，防音パネルの場合に関しても，PV パネルのリサイクルを実 施することで， $\mathrm{CO}_{2}$ 削減効果は正の結果を示した。このことにより， リサイクル事業を進めることで逆に環境負荷を増加させるという結 果にはならないことが判明した。廃棄物減容化の効果と併せて, 使 用済み PV パネルの建材へのリサイクルは環境負荷削減効果をもた らすことが示された。

\section{4. まとめ}

使用済み PV パネルの処理業者, 及びガラス再資源化製品製造メ 一カーに対するヒアリング調査をもとに， PV パネルガラスを用い た再資源化による $\mathrm{CO}_{2}$ 削減効果をインベントリ分析により算定した。 主な結果を以下に示す。

・PV パネルを再資源化する際, その主な構成品目であるガラスを再 生原料としてタイル, ブロック，防音パネルなどの建材を製造する ことで現状工程（廃棄後, 製鍊スラグ化し路盤材と利用する）と比 較して，10\%以上の $\mathrm{CO}_{2}$ 削減効果が得られることを示した。 $\mathrm{CO}_{2}$ 削 減量はタイルへと再資源化した場合で $310 \sim 442 \mathrm{kgCO}_{2} / \mathrm{t}^{\prime}$ ，ブロッ ク，防音パネルで 142〜 $238 \mathrm{kgCO}_{2} / \mathrm{t}^{\prime}$ となることを明らかにした。

・タイルへの再資源化時には原料にガラスを用いたことによる燃料 削減効果が $\mathrm{CO}_{2}$ 削減に大きく寄与することが確認された。

・埋立処理と比較した場合においても, 単結晶系 PV パネルをタイル へと再資源化することで, $227 \mathrm{kgCO}_{2} / \mathrm{t}^{\prime}$ の削減量が得られることを 示した。

今後は, 地域ごとの使用済み PV パネルの廃棄量の推定に基づく再資
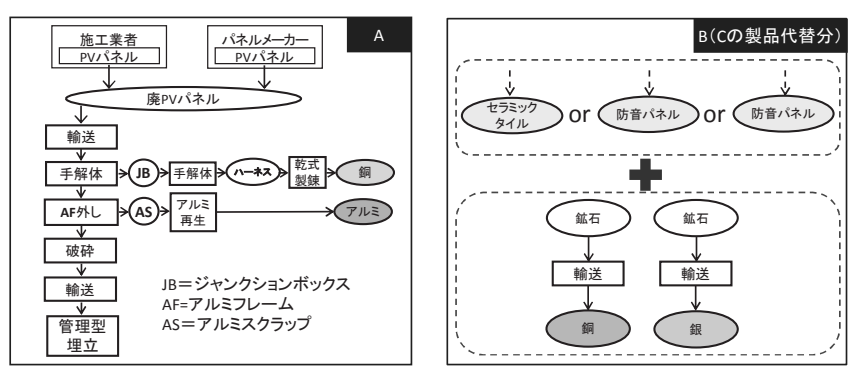

図 5 工程 A,B（工程 A一埋立処理時）

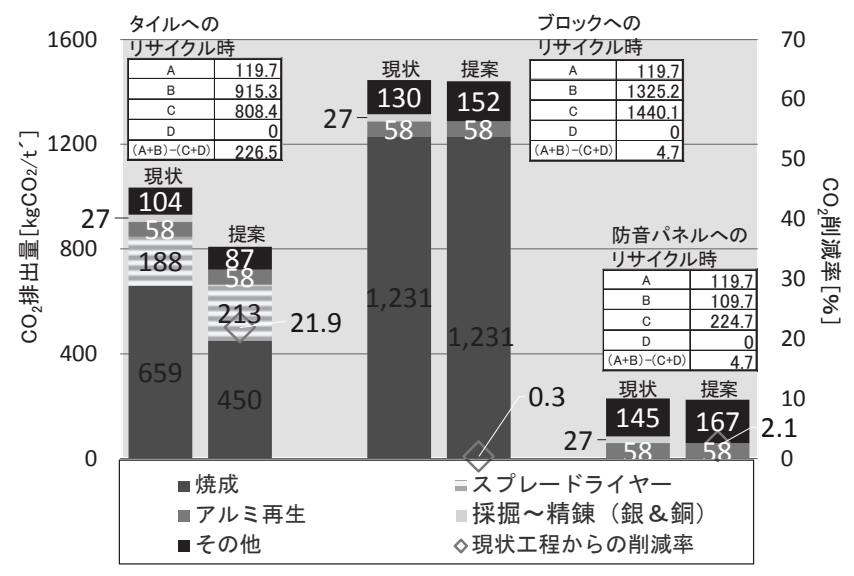

図 6 再資源化実施時の $\mathrm{CO}_{2}$ 排出量内訳 (単結晶系 PV パネル, 工程 $A$ 一埋立処理の場合)
源化工場の分散配置計画等を行う必要がある。その際には, 地域の 廃棄量に基づく再資源化工程の機器仕様の最適化, 現実的な輸送距 離の見直し等が課題となる。また, 本報における埋立処理との比較 では, 埋めるまでのプロセスを評価対象としたが, 最終処分場自体 の環境負荷を検討することも必要と考えられる。

\section{謝辞}

本研究の調査にご協力を頂いた企業および関係者に感謝します。 また, インベントリ分析にあたって, 株式会社レノバの本田大作氏 には貴重なご意見を賜り，感謝します。

注

注 1)評価対象としたガラス再資源化製品は参考文献 14)に記載されている外 装用磁器質タイル $(150 \times 150 \times 13 \mathrm{~mm})$, 舖装用床ブロック $(200 \times 100$ $\times 60 \mathrm{~mm} ）$ ，屋内外の騒音対策用ガラス発泡防音パネルとした。

注 2) 輸送プロセスはヒアリング対象の工場間の距離を参考に設定值を設けた が, 日本全体の将来的な廃 PV パネル発生源とリサイクル工場間等の距離は 本論の設定值より大きくなる可能性がある。但し, 輸送プロセスにおける $\mathrm{CO}_{2}$ 原単位は相対的には小さく, 工程 $\mathrm{C}$ の場合, 廃 $\mathrm{PV}$ パネルのリサイクル 工場までの輸送に関わる $\mathrm{CO}_{2}$ 排出量が工程 $\mathrm{C}$ に占める割合の増加は, 距離の 設定を $100 \mathrm{~km}$ 延長するごとに $0.6 \%$ 程度であることを確認している。

\section{参考文献}

1) 環境省大臣官房廃棄物・リサイクル対策部企画課リサイクル推進室：太陽 光発電設備のリサイクル等の推進に向けたガイドライン，2016.3

2) 環境省：太陽光発電設備等のリユース・リサイクル・適正処分に関する報 告書, 2015.6

3) 岡島敬一, 内山洋司：リサイクル技術を考慮した太陽電池ライフサイクル 評価，LCA 学会誌，Vol. 5, No4, pp. 521-528，2009.10

4) 張玄庚, 醍醐市郎, 松野泰也: マテリアルフロー分析による日本における ガラスのリサイクル可能性評価, LCA 学会誌, Vol.6, No. 4, pp. 288-294, 2010. 10

5) 醍醐市郎, 張玄庚, 松野泰也: 使用済み自動車からの板ガラスリサイクル の環境性および事業採算性評価, LCA 学会誌, Vol. 7, No. 1, pp. 72-78, 2011. 1

6) 清家剛, 磯部孝行：他産業も含めたマテリアルフローを考慮した建設系廃 棄物の再資源化評価システムの構築に関する研究, 日本建築学会構造系論 文集，第 78 巻，第 683 号，pp. 17-26，2013.1

7) 茂呂隆, 多葉井宏, 高口洋人: リサイクル建築資材製造時の環境負荷原単 位に関する研究, 日本建築学会環境系論文集, 第 595 号, pp. 113-119, 2005. 9

8) CFP プログラム web サイト, 社団法人産業環境管理協会: カーボンフット プリント制度試行事業 $\mathrm{CO}_{2}$ 換算量共通原単位データベース, Vol4, (http://www. cms-cfp-japan. jp/calculate/verify/data. html) (参照 2016. 10.24)

9) 社団法人産業環境管理協会：JEMAI-LCA Pro\&オプションデータパック, 2003

10) 日本アルミニウム協会：スクラップ溶解のインベントリ調查報告書, 2007. 9

11) 成田暢彦, 田原聖隆, 匂坂正幸, 稲葉敦：貴金属（金, 銀, 白金）のイン ベントリ分析 $-\mathrm{CO}_{2}$ 排出に着目して一, 第 1 回日本 $L C A$ 学会研究発表会講演 要旨集, pp. 74-75, 2005. 12

12) 環境省：算定・報告・公表制度における算定方法・排出係数一覧

13）日本工業規格 JIS：C 4210，2001

14) 株式会社レノバ：使用済太陽光パネルユニットの新たなリサイクル・リユ ースシステムの構築実証事業報告書, 環境省 HP, 2016.2

15) 湯淺和博, 山崎成, 鶴崎敬大：使用済太陽光パネルのリサイクルに関す る研究, 第 1 報インベントリ分析の前提条件, 日本建築学会大会学術講演 梗概集，環境工学 I, pp. 1393-1394，2016.8

16) 山崎成, 湯淺和博, 鶴崎敬大: 使用済太陽光パネルのリサイクルに関す る研究, 第 2 報 $\mathrm{CO}_{2}$ 排出量の削減効果, 日本建築学会大会学術講演梗概集, 環境工学 I , pp. 1395-1396, 2016.8 


\title{
ENVIRONMENTAL LOAD REDUCTION EFFECT \\ BY RECYCLING USED PHOTOVOLTAIC GENERATION PANEL GLASS
}

\author{
Kazuhiro YUASA*, Takahiro TSURUSAKI** and Sei YAMASAKI***
}

* Assoc. Prof., School of Environment and Society, Tokyo Institute of Technology, Dr.Eng.

** Grad. Student, Graduate School of Science and Engineering, Tokyo Institute of Technology (Jyukankyo Research Institute Inc.)

*** Grad. Student, Graduate School of Science and Engineering, Tokyo Institute of Technology (Currentry, Takenaka Corporation)

The demands of photovoltaic generation (PV) are increasing as the public eco-awareness grows, but there is concern of enormous volume disposal of PV panels in the near future. It is calculated by Ministry of the Environment that if the PV panels life expectancy were 25 years, its final disposal amount reaches 800,000 ton in 2040. And its disposal amount is equivalent to $6 \%$ of the present final disposal amount of whole Japan. Considering the load to future's final disposal site, its influence can't be ignored any more.

For this reason, some companies are already working to develop the recycling method of PV panels in Japan. However, details of its reductive effect of environmental load is not so certain. So the purpose of this study is to uncover the reduction in CO2 emissions by the recycling of PV panel's glasses (main constituent materials of PV panels are glasses which accounts for more than $50 \%$ by the weight ratio.) through the inventory analysis.

At first, we carried out hearing survey on PV panels disposal service vendors, recycled products manufacturers and so on, in order to grasp component materials of PV panels (5 kinds of PV panels were targeted in this research), manufacturing process of recycled products, specification of prosessing apparatus, etc.

Then we set two flow charts based on hearing survey. First are proposal procedures that are processes of PV panel's glasses recycling to ceramic tiles, paving blocks, and sound proof panels. Second is currently procedure as a comparison that is process of PV panels recycling to roadbed materials (we also considered that currently procedure is landfill disposing without PV panel's glass recycling). We calculated respective procedure's CO2 emissions per PV panel ton treatment by the inventory analysis.

The followings are the main findings of this study:

- Each of PV panels are composed of different materials ratio, so there are difference of reduction in $\mathrm{CO} 2$ emissions between respective PV panels.

- At the time of recycling to ceramic tiles, it was confirmed that the fuel consumption in the baking process can be reduced $33 \%$ by using glass, not a natural raw material like a feldspar. Therefore, the substantial CO2 reduction effect was suggested.

- Recycling to ceramic tiles, paving blocks and sound proof panels using glass of PV panels gave more than $10 \% \mathrm{CO} 2$ reduction ratio, even when any PV panels were subjected. It was the case when CIGS PV panels are recycled to sound proof panel that the $\mathrm{CO} 2$ reduction ratio becomes biggest, and its $\mathrm{CO} 2$ reduction ratio was $61 \%$.

- We showed that which productization or occasion of PV panel kinds are able to get the amount of CO2 reduction beyond $140 \mathrm{~kg}-\mathrm{CO} 2$. It was the case when CIGS PV panels are recycled to ceramic tiles that the amount of $\mathrm{CO} 2$ reduction becomes biggest, and its amount of $\mathrm{CO} 2$ reduction was $441.6 \mathrm{~kg}-\mathrm{CO} 2$.

- Amount of $\mathrm{CO} 2$ reduction didn't become substantial minus effects in the comparison even when the currently procedure is landfill disposing. Combined with the volume reduction of final waste, it is suggested that PV panel recycling reads to significant reduction of environmental load.

（2016 年 12 月 9 日原稿受理，2017 年 7 月 18 日採用決定） 